\title{
Environmental impact of disposing of mouth covers, masks or respirators what alternatives do we have?
}

\section{Impacto ambiental del desecho de cubrebocas, mascarillas o respiradores ¿Qué alternativas tenemos?}

\author{
HERNÁNDEZ-RODRÍGUEZ, María Guadalupe*†, ORTEGA-CHÁVEZ, Laura Antonia, \\ GALLEGOS-OROZCO, Carmen Angelina and CARO-ESCUDERO, Iveth Selene
}

Tecnológico Nacional de México/ Instituto Tecnológico de Chihuahua II, Mexico.

ID $1^{\text {st }}$ Author: María Guadalupe, Hernández-Rodríguez / ORC ID: 0000-0001-7278-7699, Researcher ID Thomson: I6541-2018, arXiv Author ID: KL3RAE-BQVMN8

ID $1^{\text {st }}$ Co-author: Laura Antonia, Ortega-Chávez / ORC ID: 0000-0001-7860-1277

ID $2^{\text {nd }}$ Co-author: Carmen Angelica, Gallegos-Orozco / ORC ID: 0000-0002-4872-4927

ID $3^{\text {rd }}$ Co-author: Iveth Selene, Caro-Escudero / ORC ID: 0000-0002-3611-2309

DOI: $10.35429 / E J R N .2021 .13 .7 .21 .27$

Received July 20, 2021; Accepted December 30, 2021

\begin{abstract}
The objective of this article is to study the different options we have to combat the environmental impact generated by the use and disposal of face masks, masks or respirators due to the pandemic that we have been suffering for more than a year (COVID-19). The growing demand for this article of personal protection has also brought with it a growing carbon footprint that we are generating towards the environment, because most of the facial masks that are used are not degradable and must be discarded after a single use. To achieve environmental sustainability, we must work and investigate other options for masks, masks or respirators that can be reused or that are biodegradable, in order to minimize the negative impact on our environment. The masks that are analyzed in this article for the raw material with which they are made are N95 and fabric masks, especially cotton ones.
\end{abstract}

\begin{abstract}
Resumen
El objetivo del presente artículo es estudiar las diferentes opciones que tenemos para combatir el impacto ambiental que está generando el uso y desecho de los cubrebocas, mascarillas o respiradores a causa de la pandemia que estamos padeciendo desde ya hace más de un año (COVID-19). La creciente demanda de este artículo de protección personal ha traído consigo también una creciente en la huella de carbono que estamos generando hacia el medio ambiente, debido a que la mayoría de las mascarillas faciales que se utilizan no son degradables y deben desecharse después de un solo uso. Para lograr la sostenibilidad ambiental debemos trabajar e investigar en otras opciones de mascarillas, cubrebocas o respiradores que puedan reutilizarse o que sean biodegradables, con el fin de minimizar el impacto negativo hacia nuestro medio ambiente. Las mascarillas que se analizan en el presente artículo por la materia prima con la que están constituidas son la N95 y las mascarillas de tela, en especial las de algodón.
\end{abstract}

Impacto, Ambiental, Mascarillas respirators what alternatives do we have? ECORFAN Journal-Republic of Nicaragua. 2021. 7-13:21-27.

\footnotetext{
* Correspondence to Author (Email: gudelariva@itesi.edu.mx)

$\dagger$ Researcher contributing first author.
} 


\section{Introduction}

Faced with the COVID-19 outbreak, the modern population found for the first time the need to use face masks, masks or respirators for any type of activity outside the home. However, these have been used for hundreds of years, dating back to the Middle Ages.

The face masks today have become an article of daily use from the governmental impositions worldwide, as their use within closed public spaces, such as shopping centers, restaurants, hospitals and other spaces becomes an indispensable requirement. . This in order to control the growing pandemic in a way that protects the possible carriers and receptors of the virus, reducing the number of positive cases due to contact or little social distancing.

What we know as face masks, as mentioned above, can have different names: face masks, masks or respirators, however, its conceptualization is the same.

According to the information guide of the Donostia University Hospital (the second largest hospital complex in Spain), face masks are personal protective equipment, and this protection provided to the user is mainly against powders, biological and cytostatic agents and other dangerous drugs. found in the air and can enter the body through the respiratory tract.

Its manufacture consists of a filtering material that traps pollutants but allows adequate breathing for the user, sometimes this quality of breathing can be supported by exhalation valves integrated into the mask itself. The rest of the mask consists of straps that are attached to the wearer's head or ears to keep them in place.

Within this same guide two types of existing face masks are specified. In the first instance, there is the surgical one, whose main function is to protect third parties by filtering the particles that the user can emit to the outside with speech or breathing, although it also protects the user from splashing biological fluids.
The second type of face masks treated are those of high efficiency FPP, these have the main function of protecting the user, since they oversee filtering the air and the particles and / or aerosols that it may contain harmful to the user if the inhale; Depending on its design, it can be: conical, horizontal and vertical. There are 3 ratings of this type of mask according to their effectiveness in combating the toxicity of contaminants concentrated in the environment: FPP1 (78\% effective filtration), FPP2 (92\% effective filtration) and finally FPP3 (98\% effective filtration).

The types of face masks mentioned above are the most used today, but also the most polluting since they are for only one use, that is why it is intended to compare this type of protection articles with those made of fabric, to determine their environmental impact and see the advantages of using one type or another.

\section{General objective}

The main objective of the article is to study the options available and present a proposal to improve the environmental problem that face masks have become since the emergence of the COVID-19 pandemic. This proposal focuses on the management of environmentally friendly materials that reduce the damage caused to the planet, as well as a correct treatment when disposing of said face masks.

\section{Theoretical framework}

As already mentioned, the rise of the face mask brings with it a new set of problems: Demand has exploded, and medical supply chains are constantly struggling to get the necessary face masks into the hands of medical workers. In addition to this, we are facing increasing contamination, which is why it is necessary to dispose of this sanitary waste in a safe way, to guarantee community health and the integrity of the environment.

The following figures or images were taken in one day, in just one block from the city of Chihuahua, Mexico, which shows the seriousness that the use of this type of mask implies and of not having them correctly once they have been used. 


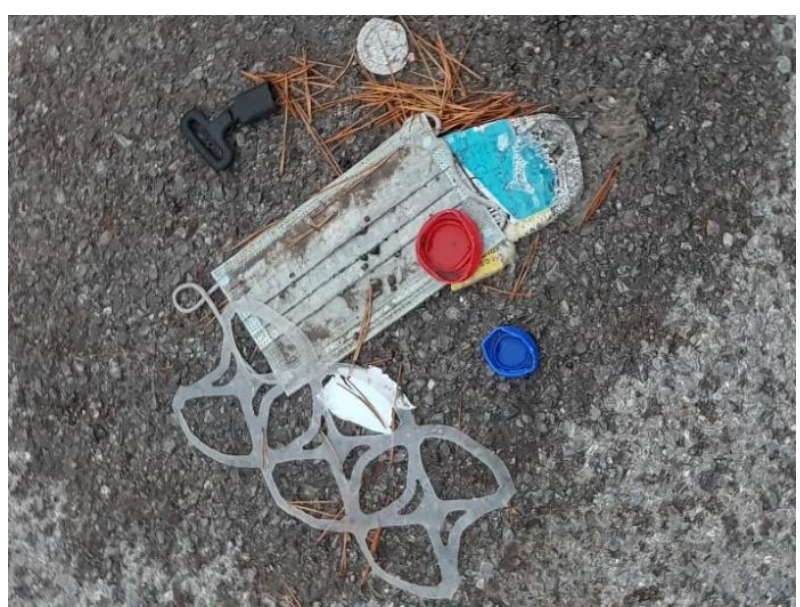

Figure 1 Surgical mask

Source: Own elaboration

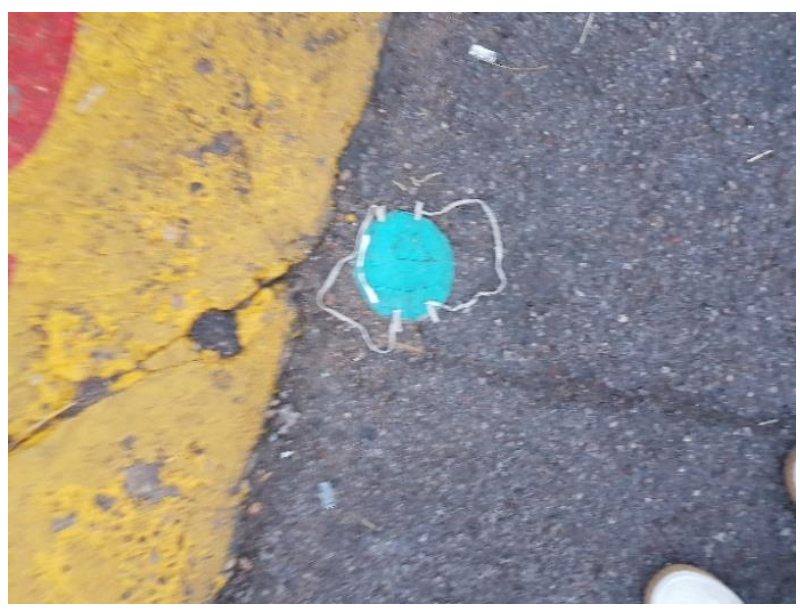

Figure 2 N95 mask

Source: Own elaboration

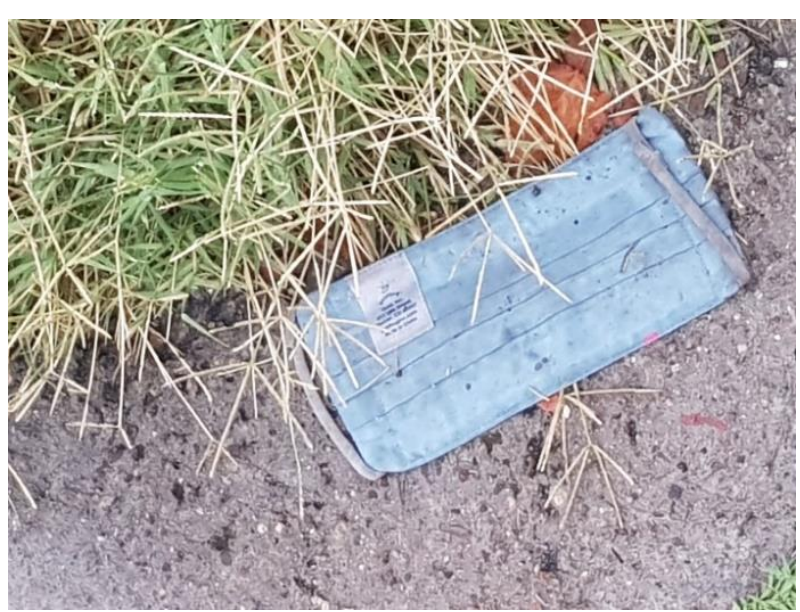

Figure 3 Surgical mask

Source: Own elaboration

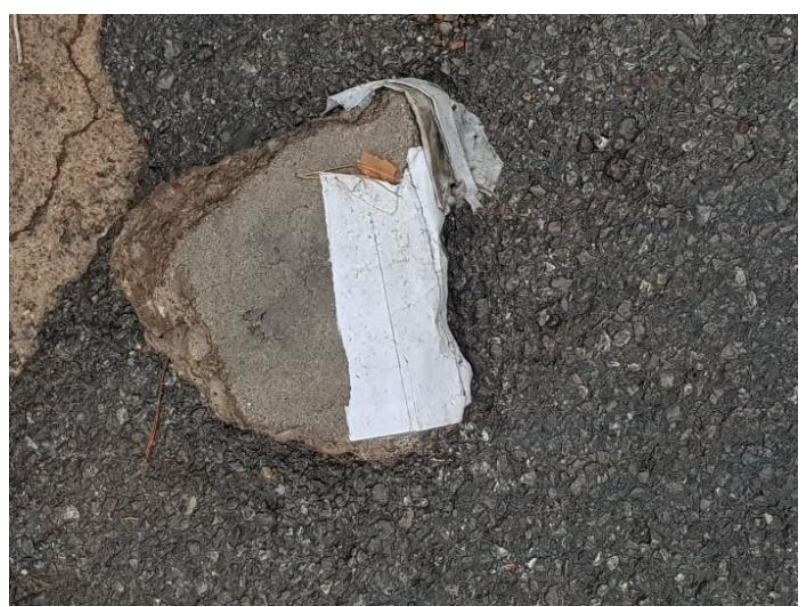

Figure 4 Face mask

Source: Own elaboration

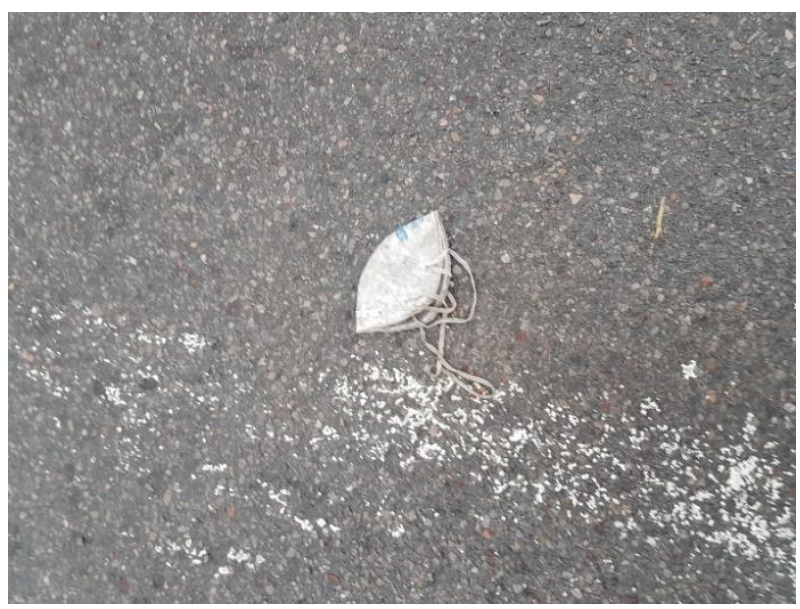

Figure 5 N95 mask

Source: Own elaboration

Right now, we need millions, if not billions of more face masks than usual. It's time to ask the question: What is the environmental footprint of all that?

That is why it is necessary to compare the carbon footprint left by these types of masks and compare it with the carbon footprint left by a cloth face masks which is more environmentally friendly. How much $\mathrm{CO} 2$ does the current need for additional face masks cost us?

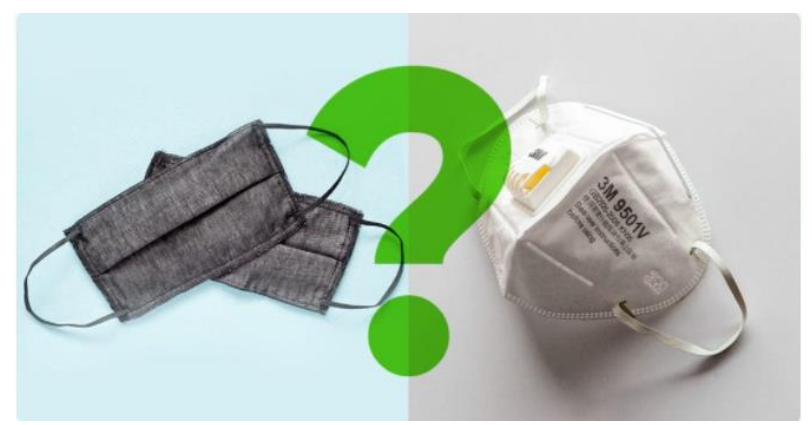

Figure 6 fabric mask Vs N95

Source: Own elaboration 
Of course, both masks serve different functions. And we are absolutely not medical experts. That is why we only look at the issue from an environmental perspective.

\section{Face masks: seemingly simple products}

Face masks are simple products. They don't require many different production steps or complicated material setups.

But this example illustrates very well how the consumption of hundreds of thousands or even millions of products causes significant environmental damage, even if the footprint of the individual product might be comparatively low.

\section{N95 face mask: what is it made of?}

This mask filters out particles and is therefore considered safe for medical workers.

N95 face masks are made of non-woven propylene (PP). They are transformed through a process called melt blown. In addition, they are attached via rubber bands, have a small aluminum strip and a small filtering accessory.

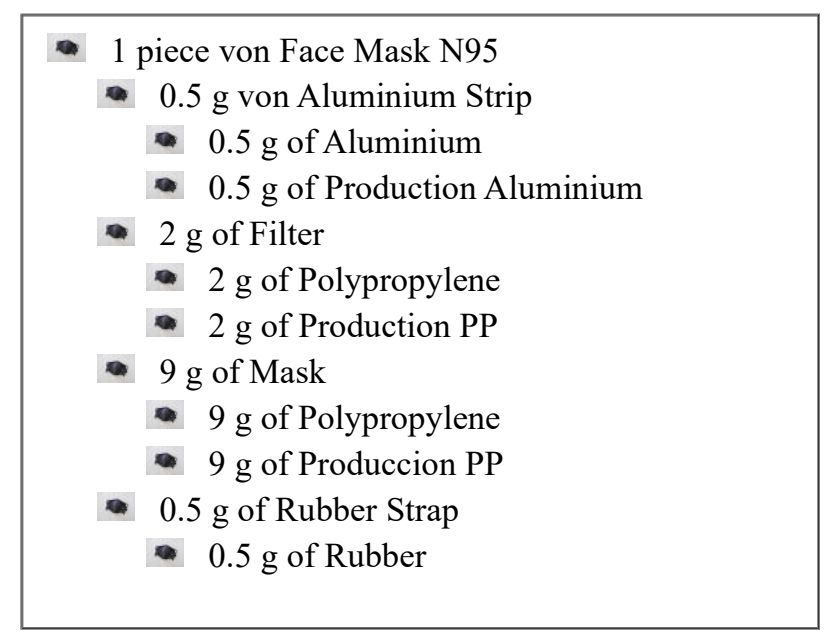

Table 1 Components of the N95 face shield Source: Ecochain

The table above shows that an N95 mask is made up of a $0.5 \mathrm{~g}$ strip of aluminum, the filter of $2 \mathrm{~g}$ of polypropylene, the mask of $9 \mathrm{~g}$ of polypropylene and the straps of $5 \mathrm{~g}$ of rubber or plastic.

The total footprint of such a mask is 0.05 $\mathrm{kg} \mathrm{CO}$ equivalent, that is, around 50 grams.

\section{Cotton or cloth face mask}

Of course, a homemade or purchased cotton mask does not have the same protective properties as an N95 mask, however it still protects the people around you, and much more is available.

How does the mask made of cotton fabric compare to the N95 mask?

1 piece of Self-made Cloth Facemask

- $12 \mathrm{~g}$ of Cloth

- $12 \mathrm{~g}$ of Cotton fabric

- $12 \mathrm{~g}$ of Weaving process

- $0.5 \mathrm{~g}$ of Rubber Strap

- $0.5 \mathrm{~g}$ of Rubber

$0.01 \mathrm{kWh}$ of Sewing

Table 2 Components of the cotton mask Source. Ecochain

Table 2 shows the components of a cloth or cotton mask in general form. 12 gr of woven and processed cotton fabric, $0.5 \mathrm{gr}$ of rubber strap and $0.01 \mathrm{Kwh}$ of sewing.

The result: $0.06 \mathrm{~kg}$ of $\mathrm{CO}_{2}$ equivalent per mask. The $\mathrm{CO} 2$ footprint of the cotton face mask is $20 \%$ higher than the footprint of the N95 protective mask.

As we can see, the carbon footprint of a fabric mask is higher than that of an N95 mask. The answer is in cotton: cotton fabric, although very small, has a relatively high $\mathrm{CO}_{2}$ footprint throughout its production cycle. Therefore, it even outperforms "artificial" polypropylene material.

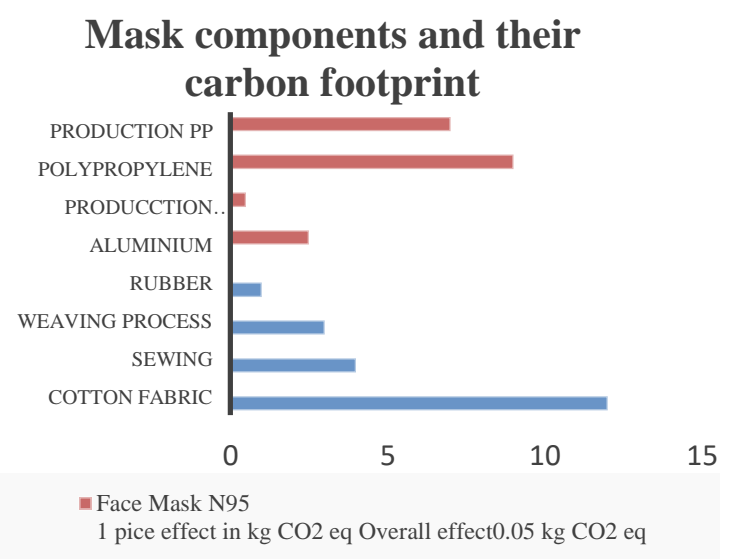

Graphic 1 Comparison of manufacturing components and carbon footprint between cloth and N95 masks Source: Ecochain 
However, these results are misleading, as they do not cover the life cycle of both types of masks.

N95 face masks are used only once, and although some people choose to use them multiple times, maximum protection can only be guaranteed with a single use.

In this case, the N95 mask turns into plastic waste on a daily basis. A medical worker would have to wear one mask per workday.

The cotton or fabric mask, on the other hand, can be used many times, of course it does not provide the same protection as an N95 mask, however, if we are not health workers, this type of mask will provide us with the necessary protection In addition, this type of mask can be washed frequently.

This is where we can observe the true carbon footprint left by both types of masks, since, for example, after 30 days of using one type of mask and another, it shows us a very different image from the one presented in graph 2 , although the following table does not contemplate the footprint left by constantly washing the cloth mask.

\section{Environmental Footprint of 30 days usage of N95 mask vs cotton mask}

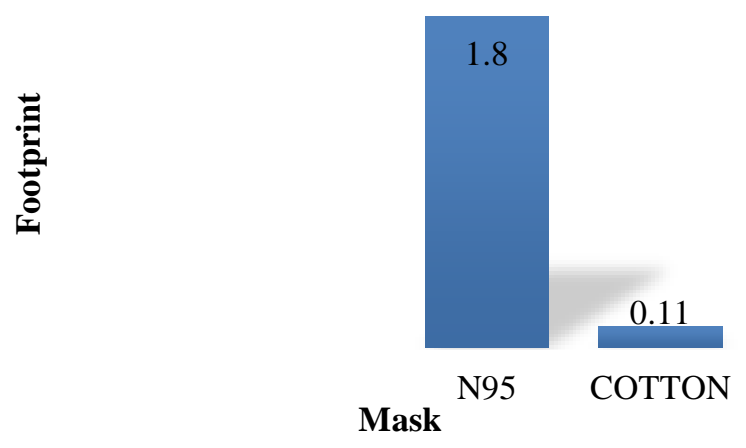

Graphic 2 Environmental footprint of 30 days of use of N95 masks Vs cloth masks

Source: Ecochain

As we can see, the environmental footprint of a single mask is comparatively low. But the problem in this crisis is not the individual mask, it is the large number of masks needed.

For example, in another study we conducted, we considered the population in the main cities of the state of Chihuahua:

$\begin{array}{lr}\text { Cd. Juárez } & 1,500,000 \\ \text { Chihuahua } & 926,000 \\ \text { Cuauhtémoc } & 180,000 \\ \text { Delicias } & 152,000 \\ \text { Total } & 2,758,000\end{array}$

If it is estimated that on average each inhabitant generates 4 used respirators per month, we would obtain 1,103,200 pieces per month in just those cities, translating this into 55.16 tons of $\mathrm{CO}_{2}$.

If we make the same estimate of 4 respirators per month, but for the entire population of Mexico, which consists of 128.97 million people, that will translate into $6,448.8$ tons of $\mathrm{CO}_{2}$ per month.

To put this in perspective, $6,448.8$ tons of $\mathrm{CO}_{2}$ equates to roughly $2,806,994,118$ mediumsized steaks (and steaks are a real climate killer for the issue of cow excrement). Driving $100 \mathrm{~km}$ with an 8-liter car produces approximately $20 \mathrm{~kg}$ of $\mathrm{CO} 2$ equivalent, which means that we could comfortably drive 42,500,000 kilometers. That's going around the world 1060 times ...

That is why we must start thinking about making changes that can have significant effects on the environment.

Of course, this is all very theoretical. But it shows how small changes to a product can make a big difference on a large scale. Because the number of masks needed in this pandemic is nothing compared to the number of single-use products that we produce and consume every day.

Imagine that a simple material change in the masks could reduce your impact by $20 \%$. With 12 billion masks required, this would save 144,000 tons of $\mathrm{CO}_{2}$ emissions.

\section{Methodology}

An exhaustive bibliographic research is carried out to collect reliable information for analysis, from which conclusions and improvement proposals for the problem presented will be obtained. 
As in all bibliographic research, we will rely on the use of secondary data as the source of our information. These will be obtained by different documents previously prepared and processed, which if they had the capacity to be based on practical realities to obtain their exposed results.

For each of the bibliographic sources used in this research project, we will ensure that the ways in which the data have been obtained and exposed are reliable, so that there are no inconsistencies or contradictions within them. They will also be a good number of different sources to analyze different points of view on the same topic.

Obtaining bibliographic sources will be online from search engines specialized in scientific articles and certified for a higher level of reliability. As well as articles from renowned magazines and portals also of a scientific nature.

This research methodology will help to find solutions to the problems raised within the research. This being possible by relating all the existing data from different sources, so that it is possible to have a broader and more systematic perspective on the environmental issues of face masks elaborated in multiple sources.

As a final result of the research, the final project will be composed based on the most important and relevant secondary data collected with which the work team is available, which will give rise to our conclusions, and the most important part, the improvement proposal according to our considerations.

\section{Conclusions}

In conclusion, it is extremely important to promote the use of reusable face masks, which we can wash daily, which is supported by the World Health Organization (WHO), and this in turn recommends that we leave it exclusively for medical personnel, people over 60 years of age and people with special medical conditions wearing medical grade or single-use masks.

Masks for non-medical use or made of materials such as fabric are highly recommended for other people who do not fall into these categories.

\section{References}

Caicoya, M. (2020). El papel de las mascarillas en el control de la epidemia COVID-19. Journal of Healthcare Quality Research, 35(4), 203205. https://doi.org/10.1016/j.jhqr.2020.05.001

Matuschek, C., Moll, F., Fangerau, H., Fischer, J. C., Zänker, K., van Griensven, M., Schneider, M., Kindgen-Milles, D., Knoefel, W. T., Lichtenberg, A., Tamaskovics, B., Djiepmo Njanang, F. J., Budach, W., Corradini, S., Häussinger, D., Feldt, T., Jensen, B., Pelka, R., Orth, K., . . Haussmann, J. (2020). The history and value of face masks. European Journal of Medical Research, https://doi.org/10.1186/s40001-020-00423-4

Choi, S., Jeon, H., Jang, M., Kim, H., Shin, G., Koo, J. M., Lee, M., Sung, H. K., Eom, Y., Yang, H., Jegal, J., Park, J., Oh, D. X., \& Hwang, S. Y. (2021). Biodegradable, Efficient, and Breathable Multi-Use Face Mask Filter. Advanced Science, $8(6)$, 2003155. https://doi.org/10.1002/advs.202003155

Selvaranjan, K., Navaratnam, S., Rajeev, P., \& Ravintherakumaran, N. (2021). Environmental challenges induced by extensive use of face masks during COVID-19: A review and potential solutions. Environmental Challenges, 3, 100039. https://doi.org/10.1016/j.envc.2021.100039

Klemeš, J. J., Fan, Y. V., \& Jiang, P. (2020). The energy and environmental footprints of COVID 19 fighting measures - PPE, disinfection, supply chains. Energy, 211, 118701. https://doi.org/10.1016/j.energy.2020.118701

Liebsch, T. (2020). The rise of the face mask: What's the environmental impact of 17 million N95 masks? Ecochain. https://ecochain.com/knowledge/footprint-face masks-comparison/

Escobar, K. M., Gonzales, M.P., Huaman, D.D., Nieves, M., Valderrama, C. A. (2020). Repositorio de la Universidad San Ignacio de Loyola: Producción y comercialización de mascarillas biodegradables a base de almidón de yuca. Repositorio Institucional USIL. http://repositorio.usil.edu.pe/handle/USIL/1026

Garduño. (2020), Mascarillas: Nueva contaminación mundial. FORBES. https://www.forbes.com.mx/noticiasascarillasnueva-forma-contaminacion-m undial/

HERNÁNDEZ-RODRÍGUEZ, María Guadalupe, ORTEGA-CHÁVEZ, Laura Antonia, GALLEGOS-OROZCO, Carmen Angelina and CAROESCUDERO, Iveth Selene. Environmental impact of disposing of mouth covers, masks or respirators what alternatives do we have? ECORFAN Journal-Republic of Nicaragua. 2021 
Global Times. (2020). The evolution of face masks. Global Times.

https://www.globaltimes.cn/content/1179358.s tml

Hospital Universitario Donostia \& OsaKidetza. (2020). Mascarillas Guía Informativa.

https://www.osakidetza.euskadi.eus/contenido s/informacion/hd_publicaciones/es_hdon/adju ntos/GuiaSL23c.pdf

Lagarón, J. M., Pardo, M. M., \& Chiva, A. (2020). DIGITAL.CSIC: Filtro multicapa con propiedades antimicrobianas y su uso en aplicaciones de respiradores y mascarillas protectoras.

DIGITAL.CSIC.

http://hdl.handle.net/10261/242170

Madyun, A. (2020). Everything you need to know about face masks. UNICEF Sudan. https://www.unicef.org/sudan/everything-youneed-know-about-face-masks

Paredes, N. (2020). Mascarillas: cuál es la mejor manera de deshacerse de los tapabocas usados para evitar la transmisión de covid-19 y la https://www.bbc.com/mundo/noticiascontaminación. 53333206.amp

UNICEF. (2020). How throw away used masks responsabily.

UNICEF. https://www.unicef.org/romania/stories/howthrow-away-used-masks-responsibly

Linder, C. (2021). Cloth Masks, Surgical Masks, or Double Masks: Which Are Safest? Popular Mechanics.

https://www.popularmechanics.com/science/hea 1th/a35290705/which-face-mask-is-best-forcovid-protection/

Schive, K. (2020). Do cloth masks actually work? MIT Medical. https://medical.mit.edu/covid-19-

updates/2020/07/do-cloth-masks-work

World Health Organization. (2020). $Q \& A$ Detail: Coronavirus disease (COVID-19): Masks. Who.Int. https://www.who.int/newsroom/q-a-detail/coronavirus-disease-covid-19masks
Carstairs, C. (2020). A brief history of masks from the 17th-century plague to the ongoing coronavirus pandemic. The Conversation. https://theconversation.com/a-brief-history-ofmasks-from-the-17th-century-plague-to-theongoing-coronavirus-pandemic-142959. 